\title{
Racismo, eugenia e doença falciforme: o caso de um programa de triagem populacional
}

\author{
Racism, eugenics and sickle cell disease: the case of a population screening \\ program
}

\section{Racismo, eugenesia y anemia de células falciformes: el caso de uno programa de selección poblacional}

Gabriela dos Santos Silva ${ }^{1, a}$

gabriella.silvaa@hotmail.com | https://orcid.org/0000-0002-9223-7405

Clarice Santos Mota ${ }^{1, b}$

motaclarice@yahoo.com.br | http://orcid.org/0000-0002-5168-7004

Leny Alves Bomfim Trad ${ }^{1, c}$

lenytrad@yahoo.com.br | http://orcid.org/oooo-0002-8762-4320

${ }^{1}$ Universidade Federal da Bahia. Salvador, BA, Brasil.

a Mestrado em Saúde Comunitária pela Universidade Federal da Bahia.

${ }^{\text {b }}$ Doutorado em Ciências Sociais pela Universidade Federal da Bahia.

c Doutorado em Ciencias Sociales y Salud pela Universidad de Barcelona.

\section{Resumo}

O objetivo deste artigo é problematizar a relação entre eugenia e racismo associada às doenças genéticas, especificamente à doença falciforme, tendo como referência o caso do Programa de Triagem Populacional (PTP), cuja implantação em Salvador, Bahia, não se concretizou devido às mobilizações sociais. Realizou-se uma pesquisa qualitativa, ancorada na perspectiva feminista e antirracista, que aliou a análise documental da proposta do programa e entrevistas em profundidade com mulheres negras com doença falciforme acerca da percepção sobre o conteúdo do programa. A análise do documento evidenciou conteúdos racistas e eugenistas, relacionados com um discurso de cerceamento do direito reprodutivo de mulheres com este agravo. Entre as mulheres negras entrevistadas, prevaleceu o sentimento de indignação frente à interdição de seu direito reprodutivo. Há necessidade de destituir práticas institucionais que se forjam sob o crivo do racismo institucional e produzem violências sobre os corpos negros.

Palavras-chave: Racismo; Eugenia; Doença falciforme; Direitos reprodutivos; Saúde da população negra.

\begin{abstract}
This article seeks to discuss the relationship between racism and eugenics associated with genetic diseases, specifically with the sickle cell disease, having as reference the case of the Population Screening Program (PTP - Programa de Triagem Populacional), which was planned to be implemented in Salvador, Bahia, Brazil, and was unsuccessful, since it was inhibited by social movements. A qualitative research was conducted, based
\end{abstract}


on the feminist and anti-racist perspective, which combined document analysis of the program proposal and in-depth interviews with black women with sickle cell disease in order to understand their perception of the program. The results indicate that the PTP proposal had explicit references to restrictions of the reproductive right of women with sickle cell disease, as well as revealed eugenics besides racist premises. Regarding the perception of the participants of the study, the feeling of indignation prevailed, especially towards the restriction of their reproductive rights. There is a need to eradicate institutional practices that are forged under a cloak of institutional racism producing violence against black bodies.

Keywords: Racism; Eugenics; Sickle cell disease; Reproductive rights; Health of the Black population.

\section{Resumen}

El objetivo de este artículo es problematizar la relación entre eugenesia y racismo, asociada a las enfermedades genéticas, en particular a la anemia de células falciformes, teniendo como referencia el PTP Programa de Triagem Populacional (Programa de Selección Poblacional), cuya implementación en Salvador, Bahía, no se ha concretado debido a las movilizaciones sociales. Se realizó una investigación cualitativa, fundamentada en la perspectiva feminista e antirracista, aliada al análisis documental de la propuesta del programa y entrevistas en profundidad con mujeres negras con anemia de células falciformes acerca de la percepción sobre el contenido del programa. El análisis del documento evidenció referencias explícitas a restricciones del derecho reproductivo de mujeres con anemia de células falciformes, presentando en muchas partes contenidos claramente sintonizados con principios eugenésicos y racistas. Entre las mujeres negras entrevistadas, prevaleció el sentimiento de indignación frente a la interdicción de su derecho reproductivo. Hay necesidad de suspender practicas institucionales que se forjan bajo el tamiz del racismo institucional y producen violencias sobre los cuerpos negros.

Palabras clave: Racismo; Eugenesia; Anemia de células falciformes; Derechos reproductivos; Salud de la población negra.

Contribuição dos autores:

Concepção e desenho do estudo: Gabriela dos Santos Silva, Clarice Santos Mota e Leny Alves Bomfim Trad. Aquisição, análise ou interpretação dos dados: Gabriela dos Santos Silva.

Redação do manuscrito: Gabriela dos Santos Silva, Clarice Santos Mota e Leny Alves Bomfim Trad.

Revisão crítica do conteúdo intelectual: Gabriela dos Santos Silva, Clarice Santos Mota e Leny Alves Bomfim Trad.

Declaração de conflito de interesses: não há.

Considerações éticas: O projeto foi aprovado pelo Comitê de Ética e Pesquisa do Instituto de Saúde Coletiva da Universidade Federal da Bahia - ISC/UFBA sob o registro 028/17.

Fontes de financiamento: Bolsa de mestrado da Fundação de Amparo à Pesquisa da Bahia (Fapesb).

Agradecimento/Contribuições adicionais: Agradecimento às mulheres participantes da pesquisa, pela confiança e disponibilidade em contar suas histórias, e a Associação Baiana das Pessoas com Doenças Falciformes (ABADFAL) por disponibilizar os documentos utilizados e acreditar nessa pesquisa.

Histórico do artigo: Submetido: 15 dez. 2019 | Aceito: 06 abr. 2020 | Publicado: 30 jun. 2020.

Apresentação anterior: não houve.

Licença CC BY-NC atribuição não comercial. Com essa licença é permitido acessar, baixar (download), copiar, imprimir, compartilhar, reutilizar e distribuir os artigos, desde que para uso não comercial e com a citação da fonte, conferindo os devidos créditos de autoria e menção à Reciis. Nesses casos, nenhuma permissão é necessária por parte dos autores ou dos editores. 


\section{Introdução}

O termo eugenia foi constituído por Francis Galton - antropólogo, meteorologista, matemático e estatístico inglês, no final do século XIX ${ }^{1}$. A eugenia se caracteriza enquanto uma ciência de melhoramento racial com a perspectiva da evolução humana, ou seja, é o uso de estratégias cientificas para aprimorar uma raça humana considerada anormal e defeituosa ${ }^{2}$.

Esse movimento apadrinhou as teorias racistas - os alicerces do genocídio do povo negro ao redor do mundo, como ocorreu com o apartheid na África do Sul, com as esterilizações em massa para fins eugênicos pelo grupo extremista Ku Klux Klan, nos Estados Unidos; e o extermínio do povo judeu, com os campos de concentração, na Alemanha².

Constata-se que é, relativamente, recorrente a menção do termo 'eugenia' associada ao holocausto judeu, no contexto da Segunda Guerra Mundial. Todavia, Nancy Stepan ${ }^{1}$ ressalta que esse episódio não é o único exemplo deste fenômeno no mundo e destaca a necessidade de estudar a "eugenia em suas formas não-nazistas" (p. 13), particularmente, de "recapturar a eugenia 'ordinária' e seus significados sociais"1 (p. 13).

As práticas eugênicas ganharam um espaço privilegiado na ciência do século XX, especialmente após os congressos internacionais de eugenia. A criação, em 1921, da Federação Internacional de Sociedades Eugênicas contribuiu para impulsionar ações nacionais com esta pauta. Cabia à comunidade científica e política desenvolver estratégias de segregação racial, com a intencionalidade de extinguir sujeitos degenerados - aqueles identificados inúteis, anormais e inábeis²

No caso da saúde, encontramos nos anos 1920 um campo discursivo 'eugenizado', sendo admitida em muitos países a "noção de que os indivíduos e grupos humanos tinham valor hereditário variável” (p. 12-13) e que tais diferenças deveriam nortear as políticas sociais'.

São salientadas também as especificidades regionais. Para Stepan ${ }^{1}$, na América Latina, foram incorporadas estratégias eugênicas que podem ser consideradas mais 'brandas', tais como as esterilizações em massa e a eugenia matrimonial, porém igualmente racistas. No Brasil, no início do século XX, "a eugenia foi saudada como uma nova ciência capaz de introduzir uma nova ordem social por intermédio do aperfeiçoamento médico da raça humana" (p. 57), ideias encabeçadas por Renato Kehl, eugenista brasileiro, criador da Sociedade Eugênica de São Paulo'.

Na década de 1930, o país encontrava-se imerso no debate sobre identidade nacional. Naquele momento, a eugenia "encontrava na noção de raça, em sua ênfase biológica, a categoria mobilizadora de uma série de reflexões" (p. 16). Floresce assim o "racialismo à brasileira" e proposições de ações para o exercício da biopolítica, "neutralizando e combatendo a degeneração em favor do melhoramento racial e da regeneração social”3 (p. 13).

O movimento eugênico brasileiro difundiu ideias para intervenções de branqueamento na população, lançando mão de ações no campo reprodutivo. Logo, "a eugenia tocou ou influenciou a história da medicina, da família, da maternidade, da população, da criminologia, da saúde pública e do bem-estar social” (p. 15). Tal movimento tinha a intenção de conduzir o processo hereditário da população, aprimorando a raça e a consequente concretização da eugenia no país, através das estratégias de políticas no campo da saúde, saneamento básico e educação. Destarte, "a eugenia foi importante porque ocupou o espaço cultural no qual se deu a interpretação social, e porque articulou novas e poderosas imagens da saúde como questão de hereditariedade e raça"” (p. 15).

Importa aqui destacar que a doença falciforme (DF) esteve historicamente vinculada ao racismo e ao processo de racialização da saúde. Segundo Chatuverdi e DeBaun ${ }^{4}$, nenhuma outra doença está tão intimamente ligada a fatores raciais, sociais e políticos quanto a doença falciforme. Nos Estados Unidos, a história natural da doença esteve desde a sua origem ligada à ideia de hereditariedade e formas de transmissão da doença ${ }^{5}$. Discursos medicalizantes usavam a DF para condenar a miscigenação e reforçar a 
ideologia da segregação racial ${ }^{5}$, de modo que médicos e cientistas estadunidenses, tais como Travis Winsor e George Burch, a compreenderam enquanto uma 'doença de negros'‘.

Já no Brasil, a miscigenação era vista como uma forma de contribuir para a eliminação da patologia7. Segundo Creary $^{8}$, a doença falciforme no Brasil evoca um processo de construção de uma cidadania biocultural, que se remete a uma origem genética, uma ancestralidade africana. Segundo a autora, esse sentimento de pertença do grupo de pessoas que convivem com a doença é uma forma de reivindicar direitos, associando o atraso das políticas públicas ao racismo ${ }^{8}$.

Apesar de ser uma doença descoberta em 1910, a implantação de políticas públicas de saúde para pessoas com doença falciforme não foi alvo de interesse do Estado brasileiro durante muitos anos. Nacionalmente, a primeira política pública foi lançada em 1996, o Programa de Anemia Falciforme (PAF), mas por falta de orçamento não teve êxito. Apenas em 2005 a Política Nacional de Atenção a Pessoas com Doença Falciforme é publicada oficialmente e passa a obter recursos do Ministério da Saúde para sua implementação.

Neste artigo, será analisado o Programa de Triagem Populacional (PTP) voltado para a identificação de pessoas com doença falciforme ou com o traço genético para DF. Para compreender a complexidade da questão em torno das políticas voltadas para um agravo genético, é importante diferenciar três modelos de triagem - neonatal, antenatal e populacional.

A triagem neonatal visa à realização do diagnóstico de doenças falciformes e outras hemoglobinopatias após o nascimento da criança, para que o diagnóstico direcione o acompanhamento com equipe de saúde o mais precocemente possível. Em geral, os primeiros sintomas da DF aparecem entre o sexto e oitavo mês do bebê, de modo que o cuidado integral a essa criança pode prevenir complicações e melhorar a qualidade de vida9.

A triagem antenatal tem o objetivo de identificar possíveis doenças genéticas e orientar a sua prevenção, isto é, a não reprodução de sujeitos com a doença, o que sugere, nesse sentido, a interrupção voluntária da gestação. Programas que visam a uma triagem antenatal são comuns em outros países, a exemplo da Inglaterra. Na Inglaterra, desde 2001, a triagem antenatal (antenatal screening) identifica mulheres com traço ou doença falciforme. No caso de exames positivos para ambos, o parceiro da mulher é convidado a realizar o teste também. Se ambos forem positivos, tanto com traço ou com a doença, a opção de interrupção da gestação é discutida com o casal, com argumentos em torno do risco de ter uma criança com a doença. Embora geneticamente a probabilidade de um casal com traço falciforme gerar uma criança com a doença seja de 25\% para cada gestação, o argumento do risco sobressai.

A triagem populacional tem a finalidade de rastrear na população quem possui o gene de uma determinada doença genética e orientá-la a não reproduzir. Esse modelo de triagem, diferente da antenatal que propõe a interrupção voluntária da gravidez, na prática, tem o intuito de reduzir sistematicamente seres humanos, não pela interrupção da gestação, mas induzido a nem chegar a engravidar - o que pode ser lida também como eugenia. Ademais, o status de ser alguém que carrega o gene, isto é, o traço falciforme, traz repercussões negativas, frequentemente associado a processos de estigmatização, além de estar associado com uma ideia de deficiência ${ }^{10}$.

Em 2001, foi implantado no Brasil o Programa Nacional de Triagem Neonatal, instituído através da Portaria $\mathrm{n}^{\mathrm{0}}$ 822/01 do Ministério da Saúde, dando início à triagem para a doença falciforme, que passa a ser incluída no elenco de doenças já testadas no teste do pezinho instituído em $1992^{11}$.

O debate em torno da DF no Brasil ocorre no bojo do debate antirracista, com intensa participação dos movimentos sociais ${ }^{12}$. O ano de 2001 foi um ano importante para as políticas de ações afirmativas, marcado pelo amplo debate sobre a saúde da população negra. Em 2001, ocorreu a III Conferência Mundial Contra o Racismo, Discriminação Racial, Xenofobia e Intolerâncias Correlatas, em Durban, na África do Sul, e a participação intensa do Brasil, especialmente do movimento de mulheres negras, permitiu avanços na agenda nacional ${ }^{13}$. 
Entretanto, na contramão desse processo, em 2004, um programa de triagem populacional é concebido na cidade de Salvador ${ }^{14}$, pelo Convênio $\mathrm{N}^{0}$ 001/2004, com o objetivo de promover através da informação e comunicação a "educação e orientação da população de Salvador, tendo como foco especial os portadores do gene falciforme e os pacientes falcêmicos"

Através de uma parceria entre a Prefeitura Municipal de Salvador, Secretaria Municipal de Saúde, Secretaria Municipal da Reparação e o Centro de Pesquisa e Assistência em Reprodução Humana (Ceparh), o programa teve como valor total de financiamento $\mathrm{R} \$ 1.164 .555,00$. Além disso, foi a primeira ação do prefeito Antônio Imbassahy, no ano de 2004, apresentada como 'um marco para saúde pública no país'.

As ações de denúncias, sobretudo da Associação Baiana de Pessoas com Doença Falciforme (Abadfal) foram fundamentais para barrar o programa, através de um documento que demonstrou preocupação em relação aos termos usados no site do programa que denotavam eugenia ${ }^{16}$. Também nesse documento, a Abadfal reivindicou a necessidade de um programa que atendesse às necessidades e demandas das pessoas com DF, tendo em vista os princípios do Sistema Único de Saúde (SUS) e o investimento na qualidade de vida dessas pessoas ${ }^{16}$.

É fato que o Programa de Triagem Populacional não chegou a ser efetivado na cidade de Salvador. Contudo, os discursos propagados pelo Programa de Triagem Populacional (PTP) ainda são disseminados, seja por meios de comunicação, seja em serviços de saúde, para pessoas com doença falciforme, especialmente as mulheres, tendo em vista a responsabilização enquanto reprodutoras da vida.

Este artigo tem por objetivo problematizar a relação entre eugenia e racismo, associada às doenças genéticas, em específico, à doença falciforme. Traz-se à tona o caso do mencionado programa de saúde proposto para ser implementado na cidade de Salvador e os relatos de mulheres negras com doença falciforme sobre ele. Versar sobre esse fenômeno nos permite despontar os corpos que estão sujeitos à eliminação, morte, ao controle e à regulação, desvelando, portanto, os acontecimentos que circularam - e ainda circulam - o mundo da ciência e das políticas de saúde, especialmente, os que dizem respeito à questão racial, às questões reprodutivas e às doenças genéticas.

A investigação sobre o Programa de Triagem Populacional, sob a perspectiva de mulheres negras com DF, principalmente referente às questões reprodutivas e raciais, traz à tona questões que agridem e violentam a população negra, contribui para a compreensão dos seus processos de vivência e o modo como seus direitos sociais são negados, e coloca em destaque a retomada de pressupostos eugenistas em programas de saúde no século XXI que, outrora, estiveram colocados no patamar de ciência e foram bússola de políticas higienistas brasileiras.

\section{Metodologia}

Trata-se de uma pesquisa convergente com uma perspectiva feminista e antirracista que se ancora nos princípios da equidade, da liberdade e no compromisso com a transformação de uma sociedade desigual que se sustenta no racismo, no capitalismo e no patriarcado. Parte-se do entendimento que, "dentro da perspectiva da transformação social, a igualdade das mulheres não é um projeto realizável dentro de um sistema cuja prerrogativa básica do seu desenvolvimento são as relações sociais desiguais” ${ }^{17}$ (p. 7). Uma pesquisa realizada a partir da perspectiva feminista e antirracista possibilita a visibilidade das mulheres negras em pesquisas acadêmicas, traçando novos discursos sobre a população negra, deslocando-a do lugar de apenas um objeto de estudo para protagonista e produtora do conhecimento.

Realizou-se um estudo qualitativo que lançou mão de duas estratégias de produção de dados: a pesquisa documental e entrevistas em profundidade com nove mulheres negras com doença falciforme e uma mulher negra com traço falciforme. Esta última foi acolhida no estudo por considerarmos oportuno atender a seu desejo de contar suas experiências de vida enquanto mulher com o traço falciforme, cujas experiências, 
conforme ela salientou, eram muito semelhantes às de mulheres com doença falciforme, incluindo a esfera reprodutiva.

O estudo foi realizado no período de março de 2017 a julho do mesmo ano. O trabalho de campo foi iniciado com a apresentação do projeto de pesquisa na reunião da Abadfal, e na finalização da reunião algumas mulheres apresentaram interesse em contribuir com a pesquisa e disponibilizaram seus telefones para um contato posterior nosso. Antes da reunião mencionada, a associação nos cedeu um termo de autorização referente ao acesso aos contatos de mulheres negras com doença falciforme para participação no estudo.

Os materiais analisados foram acessados através da biblioteca da Abadfal e são eles: a Carta Aberta à População - Convênio Cephar - Secretaria Municipal Saúde Salvador/BA; o Termo de Declaração sobre o questionamento da regularidade do Convênio no 001/2004 ao Ministério Público do Estado da Bahia - MPBA; a Carta ao Comitê de Hemoglobinopatias do Ministério da Saúde e Gerência Sangue Anvisa; o registro da criação do site www.falcemia.med.br/presente.html; e os Diários Oficiais do Município de Salvador/BA datados de 8 e 12 de janeiro de 2004.

Participaram da pesquisa dez mulheres negras, das quais nove têm doença falciforme e uma apresenta o traço falciforme, com idade variando entre 20 e 49 anos de idade. As ocupações referidas foram: donas de casa, curso técnico em andamento, técnica de enfermagem, autônoma, analista de relacionamento digital, contadora, auxiliar administrativa e pesquisadora. A escolaridade das interlocutoras variou entre ensino médio incompleto e ensino superior completo.

Entre as dez interlocutoras, seis (Anastácia, Aqualtune, Carolina Maria de Jesus, Dandara, Laudelina de Campos e Tereza de Benguela) têm filhas(os), e quatro (Lélia Gonzalez, Luísa Mahin, Maria Felipa e Zeferina) não têm filhas(os). As interlocutoras são residentes de bairros periféricos e populares de Salvador e são de famílias de baixa renda. Vale ressaltar que, para preservar sua privacidade, os nomes das interlocutoras foram substituídos por nomes de heroínas negras, mulheres que lutaram por liberdade e igualdade desde o período colonial brasileiro. Tais mulheres precisam ser visibilizadas para que suas histórias não se percam e não sejam apagadas.

O primeiro contato com as interlocutoras ocorreu através do aplicativo WhatsApp e consistiu na apresentação sucinta da pesquisa e entrega da carta-convite. Os encontros ou contatos presenciais foram realizados em quatro lugares distintos, de acordo com a escolha das interlocutoras - sala da Abadfal, shopping, local de trabalho e serviço de saúde.

As entrevistas tiveram duração média de 40 minutos, foram gravadas e, posteriormente, transcritas. Foi adotado um roteiro formado por três blocos temáticos: conviver com a doença falciforme, percepção e experiências sobre direitos reprodutivos e percepção sobre o Programa de Triagem Populacional - bloco que apresentaremos neste artigo. No bloco do conteúdo desse programa, foram apresentados às interlocutoras nove trechos extraídos de sua página eletrônica, hoje já desativada, conforme descritos no site www. falcemia.med.br/presente.html. Os trechos selecionados eram lidos individualmente, e a cada leitura elas colocavam as suas percepções - o que, na maioria das vezes, eram impressões de total discordância com o programa e indignação frente ao conteúdo - o que fazia com que elas colocassem mais questões das suas experiências e as relacionassem com as questões reprodutivas e raciais.

Adotou-se a análise do discurso na linha de Michel Foucaul $\mathrm{t}^{18}$, segundo o qual o discurso constitui um "conjunto de enunciados"18 (p. 132) amparados na própria formação discursiva, e se apresenta nos sujeitos e nos espaços institucionais entendendo a intervenção dos contextos sociais, culturais e políticos. Assim, o discurso é social e histórico. 


\section{Resultados e discussão}

\section{O Programa de Triagem Populacional - uma eugenia à brasileira?}

O Programa de Triagem Populacional (PTP) foi proposto com o objetivo principal de identificar pessoas com traço ou doença falciforme para, através da informação, orientá-las a não reproduzirem, com base na premissa de que "a única ação capaz de modificar favoravelmente as estatísticas no curto/médio prazo é a triagem populacional dos adultos em idade fértil, com informação sobre o significado reprodutivo da HbS nos portadores de um gene de hemoglobinas anômalas"19.

Existem evidências que a DF apresenta uma maior incidência na população negra e, como a reprodução da vida se dá por intermédio das mulheres, a quem esse programa iria atingir prioritariamente se não as mulheres negras com doença falciforme?

$\mathrm{O}$ argumento central para justificar a sua implantação era a necessidade de reduzir custos com o tratamento da DF. Contudo, ao lado da pretensa busca de eficiência, a proposta destacava outras finalidades, cujos enunciados revelam a sintonia com o ideário eugenista, como podemos ver neste trecho apresentado no site: o programa era "fruto de um antigo e fascinante projeto de ciência aplicada, capaz de beneficiar - em nosso meio, a baixo custo - 'uma nova geração de pessoas' [...] que nascerão saudáveis no lugar dos que seriam concebidos com genes de hemoglobinas mutantes"19 (destaque nosso).

O uso dos termos adotados pelo programa advertem um discurso carregado de preconceitos e estigmas referentes às pessoas com DF. As palavras 'portadores' e 'doentes' reforçam a exclusão e a segregação, e a doença se transforma na principal característica da pessoa com DF, em detrimento de sua condição humana. O programa afirma que "[...] o número de doentes com anemia falciforme - portadores do genoma HbS/ $\mathrm{HbS}$ - é inaceitavelmente alto em nosso meio. E nada, jamais, até hoje foi feito para 'reduzir no curto/médio prazo essa elevada prevalência da doença entre nós"”19 (grifo nosso).

Durante as entrevistas, as interlocutoras deste estudo sentiram-se indignadas ao lerem os objetivos e a justificativa do PTP. A reação ao contato com o conteúdo do programa foi de total reprovação. Ao analisar o objetivo do programa, problematizam os enunciados presentes no site, ressaltando a relação com o direito reprodutivo:

\section{[...] extingue, né, a raça humana. Só porque tem essa doença vamos extinguir sim, vai ter que extinguir} todos os doentes. (Dandara).

[...] e também não tem como não deixar essas pessoas nascerem, [...] não é tá deixando de existir pessoas, entendeu? Aí você tá tirando o direito da pessoa de reproduzir, não é nascer genes saudáveis, é deixar de existir as pessoas com anemia falciforme, entendeu? (Teresa de Benguela).

O aperfeiçoamento dos seres humanos - tanto pela via do cerceamento dos direitos reprodutivos quanto pela eliminação dos ditos 'doentes' e 'improdutivos' - com o desígnio de privilegiar o nascimento de pessoas brancas, lidos enquanto sujeitos produtivos e saudáveis, serviu perfeitamente como instrumento do racismo ${ }^{18}$. A tais ações, que promoveram “tragédias genocidas" ${ }^{20}$ (p. 89), vestidas de ciência, denominase eugenia ${ }^{20}$.

A perspectiva eugênica, na América Latina, tinha o gênero como um marcador basilar, pois "era pela reprodução sexual que ocorriam a modificação e a transmissão da conformação hereditária das gerações futuras"1 (p. 116). A eugenia "estabelecia novas normas científico-hereditárias e controles da reprodução que não implicavam 
métodos cirúrgicos radicais” (p. 116). Assim sendo, se constituiu um modo particular da eugenia negativa - a eugenia matrimonial ${ }^{1}$, que, a partir do controle da reprodução, conduziu os movimentos eugênicos.

No Brasil, uma das táticas da eugenia matrimonial eram os exames pré-nupciais, pois, segundo eugenistas brasileiros, os exames impediriam o casamento de pessoas lidas como "improdutivas" e "inadequadas" sem recorrer aos métodos de esterilizações ${ }^{1}$ (p. 131). Princípio semelhante pode ser extraído da proposta do PTP. Após a triagem, os casais - ou apenas as mulheres - seriam aconselhadas(os) a não reproduzirem, por conta do risco reprodutivo, isto é, "a finalidade é orientar as famílias sobre os riscos da reprodução de um 'doente' através do 'gene mutante"'19.

Este aspecto do PTP é problematizado por Dandara, que compara essa ação a de um "cativeiro", onde as pessoas com doença - os "problemas" - estariam sendo preparadas para o abate - a sua eliminação. Dandara coloca, ainda, que a DF, nesses moldes, é como se fosse algo transmissível apenas pelo toque.

Ele tipo assim, um cativeiro coloca todas as pessoas, eu vejo assim, em um lugar cercado, só aquelas pessoas que têm aquela doença ali, pra não proliferar [...]. Então isso é horrível, a gente sente até mal com isso [...] (Dandara).

O teor eugênico produzido pelo programa é algo que já foi desenvolvido no Brasil nos anos 1930, sob uma perspectiva de desenvolvimento de uma nova raça e a busca pelo aperfeiçoamento da população brasileira. Estratégias ancoradas em ações eugênicas desaguaram em políticas de intervenções focadas, sobretudo, nas mulheres ${ }^{21}$. A regulação da população - enquanto estratégia para evitar o nascimento de doentes - era frequente nas políticas sociais do Estado, por meio do controle dos nascimentos, dos casamentos e dos comportamentos, descritos como 'taras e vícios' ${ }^{21}$. Stefan ${ }^{1}$ argumenta que, nesse período, o nacionalismo na América Latina apresentava um intenso caráter de homogeneização, por isso o destaque na questão racial.

A questão racial foi um elemento central identificado na análise do programa. Enquanto expôs a história da escravidão no Brasil - tráficos de pessoas escravizadas e miscigenação - assinala o elemento da incapacidade das pessoas com doença falciforme. O programa descreve que no período colonial no Brasil, as crianças com DF morriam precocemente, e "esses pacientes eram negros ou mulatos, pobres, a quem historicamente pouca atenção se ministrou, senão quando dos gemidos decorrentes das dores terríveis nas crises quando precisavam de sedativos fortes" ${ }^{\prime 19}$.

Há uma ressalva no site do programa marcando que a doença falciforme atinge não só a população negra, mas também a branca. No entanto, o conteúdo do programa foca em Salvador por ser a cidade mais negra na América do Sul, além do enfoque no continente africano. Logo, trazer o perfil da população de Salvador, assim como das crianças na época do Brasil Colônia, não tem o objetivo de fomentar as discussões acerca de políticas de saúde para a população negra, que trabalhem com a integralidade e equidade, visando à redução das iniquidades raciais e sociais, mas sim para justificar o porquê da necessidade de se prevenir o 'nascimento de seres doentes'.

Maria Felipa entende que o programa não tinha a intenção de investir na população negra, que outrora foi a população escravizada. Assim, além de investir na atenção à saúde desse grupo, teria também que desenvolver ações em torno da educação, do trabalho, por exemplo, o que o programa não tinha nenhuma perspectiva.

Então tipo, bora acabar com os negros. Por que negro, além de ser mais caro e aí tipo, não é só a doença, porque se você for cuidar da doença, você tem que cuidar da parte social, você tem que cuidar [...]. São muito mais despesas, entendeu? E tipo, é um trabalho que você dá e você vai tá ajudando a quem? Aos escravos? Entendeu? (Maria Felipa). 
Nas proposições do PTP havia uma divisão entre os sujeitos 'doentes' e 'não doentes', sendo os 'doentes' as pessoas com DF. O programa materializava a ideia de que as políticas de saúde deveriam ter como suporte as características biológicas e a seleção dos genes saudáveis. No conteúdo presente no site, há o seguinte trecho: “[...] também conhecida por Falcemia, trata-se de uma doença hereditária potencialmente incapacitante [...]. E os doentes são improdutivos, e os seres humanos sem doença são produtivos. [...] situação na qual a maioria dos portadores são doentes sofridos, pobres, indesejáveis nas unidades de emergência, incapacitados para o trabalho e para a vida"19. O programa apresenta ainda que se deveria "ATUAR AGORA, sobre um PROBLEMA QUE EXISTE HOJE, para tê-lo reduzido AMANHÃ "19. Do mesmo modo, uma das interlocutoras realça,

[...] eu não pedi pra nascer com a doença, mas eu tô aqui e quero viver [...]. Muito pesado, ninguém pede pra nascer doente, é muito pesado [...] (Carolina Maria de Jesus).

Tal ideia emitida pelo programa é semelhante ao discurso nazista que pregava a 'morte' das pessoas incapacitadas, devido à sua ineficiência para a produção do trabalho. Além disso, vai de encontro a toda uma literatura acerca das pessoas com DF e as atividades exercidas nas suas trajetórias. A doença falciforme não é fator impeditivo para o exercício do trabalho ${ }^{22}$.

As pessoas com doença falciforme, geralmente, convivem com a enfermidade desde a primeira infância, à medida que vão crescendo aprendem e desenvolvem formas de enfrentar as adversidades e minimizar o impacto da doença em seu cotidiano ${ }^{22}$. Umas das principais barreiras que as pessoas com DF enfrentam em relação ao trabalho é a resistência das empresas para contratar, uma expressão do racismo institucional ${ }^{23}$. Portanto, a redução do nascimento de pessoas com DF não é a "solução para resolver o problema de acesso ao mercado de trabalho"22(p. 112).

Destarte, ao articular para que não existam mais pessoas com doença falciforme, o Programa de Triagem Populacional marca uma relação da eugenia com o genocídio da população negra e a intervenção no direito da mulher decidir sobre seu corpo e na sua autonomia reprodutiva.

\section{Estratégias de prevenção previstas no Programa de Triagem Populacional}

No documento do PTP havia uma afirmativa que dizia: “[...] a prevenção é, portanto, escopo central para a sociedade [...] cujo efeito deverá ser a redução, nas próximas gerações, do nascimento de seres humanos, portadores da anemia falciforme" ${ }^{\prime 19}$. Ressalta-se aqui que, em se tratando de uma doença genética, o uso do termo prevenção pode ser interpretado como uma ação de eugenia.

Maria Felipa enfatiza que a noção de prevenção emitida pelo programa impactaria, caso fosse efetivado, o genocídio de cerca de 50 mil pessoas, considerando as com traço e doença falciforme.

A gente não vai deixar nem nascer. Não é nem nascer. Não vai chegar a nascer. Antes disso, vumbora evitar. [...] Quando você corta metade da população, um tipo de pessoas, você está matando né? É eugenia [...]. Essa parcela da população não vai existir. Não é uma pessoa, duas pessoas. São o quê? Aqui, em torno de 50 mil? Aqui, na Bahia?” (Maria Felipa). 
Igualmente, Anastácia e Lélia Gonzalez corroboram:

É assustador, filme de ficção científica [...]. Não nascer? Quer tirar um grupo [...]. (Anastácia).

Mas não se previne [...]. Não se previne anemia falciforme, é uma doença genética que [...]. Eu não concordo com isso não, não vou nem falar [...]. (Lélia Gonzalez).

A triagem neonatal foi descrita no programa como uma das estratégias de prevenção da doença falciforme. O programa pondera que “[...] a triagem neonatal é a PREVENÇÃO PARA O FUTURO - se o resultado do teste não se perder ao longo do tempo, cada portador do traço falcêmico (um gene HbS) detectado na infância terá consciência do fato quando estiver apto a reproduzir"19. Logo, desde o nascimento até a vida adulta com idade reprodutiva, o sujeito saberá da sua condição genética e dos riscos da reprodução.

O documento do PTP afirma que “[...] cada novo doente é uma injustiça social, uma vez que é 'comprovadamente possível prevenir o nascimento de novas pessoas afetadas', através da tecnologia médica e do uso honesto da informação e da comunicação social”19 (destaque nosso).

Tanto Tereza de Benguela, quanto Maria Felipa apresentaram indignação ao ouvirem que elas são uma 'injustiça social', concepção essa enfatizada pelo programa em todo o seu conteúdo. Tereza de Benguela reafirma que a sociedade, sim, é que se apresenta como um fardo para as pessoas com DF, tendo em vista toda a sua estrutura opressora e os obstáculos que essa parcela da população enfrenta para ter direito à saúde, trabalho, educação e lazer. Maria Felipe expõe sua repulsa ao programa:

O uso honesto da informação é dizer que você não pode nascer? Ou você é uma pessoa podre, entendeu? Um fruto podre, então bora descartar! Isso é uso honesto? Vai usar a comunicação social pra falar, "Ah, a partir de agora vamos usar a mídia pra dizer que pessoas com DF precisam" [...]. "A gente precisa evitar". Como ele não pode sair matando todo mundo, a gente, ele proíbe o nascimento. Pronto, daqui um tempo não nasce mais ninguém, tá tudo certo, né? (Maria Felipa).

Maria Felipa questiona a concepção de honestidade do programa de triagem populacional, distinguindo-o como uma "máquina de matar pessoas com DF", além de pretender utilizar informações deturpadas e carregadas de estigmas das pessoas com DF para orientar a não reprodução de "doentes". A interlocutora destaca também, no seu discurso, a ausência do Estado no que diz respeito a garantir os direitos sociais básicos.

Outra proposta do programa exposta no site era: “[...] desenvolver ação conjunta de saúde pública com a triagem populacional, para hemoglobinopatias mutantes e o 'devido aconselhamento genético, a partir da amostra de população de baixa renda"'19 (destaque nosso). O aconselhamento genético aparece como peça-chave para alcançar a desejada prevenção de pessoas com DF. A informação, assim, seria um dos principais instrumentos utilizados, e a sua eficiência estaria condicionada à "qualidade da comunicação e educação das comunidades para lidar com o problema" 19 .

O aconselhamento genético é um direito das pessoas com doença falciforme, e as mulheres - se assim quiserem - possuem o direito de fazer a eletroforese e ser informada da sua condição genética, sem que com isso sejam persuadidas a fazer escolhas referentes à reprodução ${ }^{24}$.

Diniz e Guedes ${ }^{24}$ assinalam que a conscientização é uma das estratégias do aconselhamento genético. O processo de conscientização, na perspectiva dos programas de prevenção à doença falciforme, estaria seguindo o caminho 'correto' se acaso os sujeitos em idade reprodutiva decidissem não ter filhas (os). Ou seja, os sujeitos já 'conscientizados' controlariam a sua reprodução, tendo em vista as elevadas chances 
de ter uma criança com doença falciforme. Neste sentido, o ato de conscientizar “[...] não era, portanto, uma medida isenta de valores ou expectativas, mas claramente uma ação que visava ao controle da reprodução por meio da racionalidade biomédica do risco"24 (p. 1058).

Por conseguinte, o programa elegia também uma determinada população a ser triada, a de 'baixa renda'. Anastácia e Zeferina, associaram essa especificidade exigida pelo programa a uma ação também racista, por entender que uma parcela da população pobre é negra. A prevenção do nascimento seria, então, voltada para as pessoas pobres e negras.

Outrora, a 'população de baixa renda' já foi alvo de políticas sociais eugenistas. A estratégia adotada pela medicina, no início do século XX, por exemplo, se transformou na prevenção, e não mais na cura, o que permite a criação de controle da reprodução e da sexualidade, principalmente naquela "[...] capaz de controlar a hereditariedade da grande família dos degenerados e, ao mesmo tempo, controlar as populações e raças consideradas perigosas: as estratégias higiênicas e eugênicas dos séculos XIX e XX [...]”25 (p. 27). As populações de baixa renda, consideradas desviantes se transformariam, portanto, alvo dessas estratégias, o que afirma, segundo a autora, a teoria da degeneração e o racismo científico. Essas estratégias foram usadas em vários países, sob a premissa da manutenção da raça e, especificamente aqui no Brasil, essas noções foram comumente adotadas pela Liga Brasileira de Higiene Mental, na sua função de condenar a mestiçagem ${ }^{25}$.

O destaque concedido no documento do PTP ao papel da informação como elemento estratégico na 'redução do nascimento de doentes'19, confirma sua base eugenista.

Para Dandara, a orientação para não reproduzir só surtiria efeito naquelas pessoas que ainda não têm conhecimento acerca dos seus direitos. De tal modo, ter conhecimento sobre sua condição de sujeito de direitos é fundamental no processo de garantia da autonomia reprodutiva, e em geral, de garantia dos direitos sociais.

Seguindo essa linha, o programa estaria indo de encontro ao respeito das escolhas individuais, se utilizando da sua condição de um programa conceituado cientificamente, e financiado e apoiado pela Prefeitura Municipal de Salvador, para exercer o seu poder e a sua verdade sobre as pessoas com doença falciforme, especialmente as mulheres negras e pobres.

O discurso médico fundamentado exclusivamente no aspecto biológico da doença falciforme evidencia uma ação de prevenção incompatível com os princípios do SUS, isto é, demonstra uma prevenção aliada aos pressupostos da eugenia e do racismo institucional, o que provocaria implicações éticas, políticas e sociais. Vale ressaltar que, ainda hoje, as interlocutoras do estudo sentem que o discurso eugenista está presente nos serviços de saúde.

\section{O não-nascimento de pessoas com doença falciforme enquanto ação de redução de gastos para o Sistema Único de Saúde}

Além da premissa de construir 'uma nova geração de pessoas', o PTP propagandeava o não-nascimento de pessoas com DF como uma efetiva ação de redução de custos financeiros para o Sistema Único de Saúde. Tal afirmativa revela-se no próprio orçamento organizado nas informações fornecidas pelo site do programa, que mencionava os custos referentes à triagem como irrelevantes, tendo em vista o cumprimento do objetivo final - a não existência de pessoas com DF, os ditos 'doentes', então, o seu desenvolvimento valeria a pena.

O programa expõe que "'tratar cada doente é sofrido e caro. Prevenir o nascimento do doente é possível' e em benefício de um imenso grupo humano, em torno de nós [...] e com informação apenas. No contexto de um programa amadurecido, dentro de uma visão realista e humanista [...]. Tecnicamente, os custos são desprezíveis; mais ainda pelo excepcional benefício, 'se considerados a eliminação de sofrimento humano e a economia de cada novo doente' que deixará de ser concebido"19 (destaque nosso). 
Dandara e Maria Felipa nos informam a lógica do programa quanto à sua intenção de reduzir os gastos.

[...] uma bala pra cada um,é a mesma coisa, é como se fosse isso, vamos eliminar essa raça aqui, essa raça tá gastando muito! Aí pra eles é fácil eliminar! (Dandara).

[...] não é aquela coisa assim, não (é) porque essa população sofre. Porque é injusto para essas pessoas sentirem essa dor, entendeu? [...] a justificativa é porque é mais barato eliminar eles. Se isso não for racismo, eu não sei o que é. (Maria Felipa).

Dandara aponta mais uma vez que o propósito do programa é extinguir uma determinada raça - que, na concepção das interlocutoras, seria a negra. Enquanto Maria Felipa entende que a proposta do programa compara as pessoas com doença falciforme como objetos, retirando todas as condições de sujeito, sua subjetividade, uma ação direta do racismo.

Para justificar o porquê 'tratar cada novo doente é sofrido e caro', o programa salienta os custos altíssimos no tratamento da doença falciforme, enfatizando que "[...] não dispomos da informação sobre o custo total da anemia de células falciformes para a sociedade, mas tanto a prevalência como a morbidade do gene são altíssimas. São dezenas de milhares de atendimentos, incontáveis exames, transfusões de sangue, gestações de altorisco, hospitalizações prolongadas, cirurgias complicadas, pacientes complexos"19.

Maria Felipa defende que os gastos com outros tipos de enfermidade seriam tão altos quanto os com o tratamento da doença falciforme. Assim, ela questiona:

A minha doença é melhor ou pior do que a doença do outro?”. É de uma injustiça incrível, incrível. [...] é mais barato evitar que eles nasçam do que cuidar deles, entendeu? Tipo, quem é que decide isso? De quem é esse poder? O sadio? Mas ele é sadio até que ponto? Ele não fica gripado, ele não tem febre, ele não é diabético, ele não tem hipertensão? Ele é 100\% saudável, pra poder ele dizer que só porque eu tenho DF, eu não posso ser? Quem é que decide isso? Entendeu? Eu acho isso de um absurdo, de uma falta de humanidade tremenda! (Maria Felipa).

Dandara e Maria Felipa apresentam questionamentos categóricos para o entendimento de uma sociedade ancorada na necropolítica, sobretudo a partir das perguntas de Maria Felipa "quem é que decide isso? De quem é esse poder?”. Achille Mbembe ${ }^{26}$ discute que os instrumentos do biopoder constituem uma política de morte, na qual se decide quem vai deixar viver e quem deve morrer. $\mathrm{O}$ autor distingue que existem corpos específicos para morrer, existem corpos marcados para viver cotidianamente sob a mira da política de morte, uma política que tem a raça como bússola. Igualmente, dentro da população escolhida pelo PTP, quais corpos seriam alvo da política de morte? Ou, até mesmo, do não direito à vida?

Evidencia-se que um dos impactos do programa na vida das mulheres com doença falciforme seria no cerceamento dos direitos reprodutivos, o direito de escolha para exercer a maternidade ou não. Posto isso, o programa seguiu afirmando que o fato de ainda existir, em nosso meio, pessoas com doença falciforme equivale a um 'absurdo ético'. Segundo ele, “[...] independentemente da situação referente à assistência médica a esses pacientes e os custos que recaem sobre o SUS, sobre a sociedade brasileira em última instância, o status quo quanto à concepção de novos portadores de anemia falciforme é um absurdo ético que vem perdurando e resistindo ao tempo em nosso meio" ${ }^{\prime 1}$. 
Podemos analisar, então, que é como se o programa compreendesse as pessoas com DF como 'nãosujeitos', pessoas que nem deveriam ter nascido. Zeferina relata esse processo:

Já tá no senso comum pra que não tenha filho, a gente viu que no fim das contas é um gasto a mais pra o Estado, é um discurso forte que a mulher com DF não tenha filho, a gente ouve isso, nossos familiares falam isso pra gente [...] Não veem por outro lado, que existe assistência. Pra eles, quem tem doença falciforme está fadado a dar gastos ao Estado e vai dar problema, prejuízo. A pessoa tem uma vida além da doença, a doença é uma parte, tem que cuidar sim, mas é uma parte da pessoa, a pessoa vive, a pessoa namora, trabalha, a pessoa estuda, e aqui tá tomando como o todo. (Zeferina).

Tal análise é corroborada por Maria Felipa. Ela afirma que, se a Constituição Federal garante o direito à saúde, e as pessoas com doença falciforme encaram dificuldades para garantir tais direitos, então elas não são sujeitas. Para além disso, são pessoas completamente descartáveis e invisíveis.

Tipo, é mais barato matar todo o mundo, não deixar nascer do que cuidar. [...] Porque como são muitas pessoas, acabam pesando no SUS, é muita gente usando o SUS [...]. E pessoa de baixa renda é a maioria no SUS. Então é realmente um gasto muito alto pro SUS. Mas é um direito. É um direito à saúde [...]. Que tá na Constituição que todo cidadão tem direito, né? Então, tipo, a gente não é cidadão, porque a gente não tem direito a essas coisas. Então, o Estado, ele precisa se equipar e se programar pra ter, receber essa população e não evitar essa população. (Maria Felipa).

O PTP afirmou que “[...] em suma, os custos vão variar de acordo com a vontade política que o programa possa despertar e alavancar [...]. Portanto, os custos diretos envolvidos serão variáveis com base no alcance do programa, no tamanho da população, nos recursos humanos alocados, comunicação, infraestrutura; e no tempo previsto para a obtenção de resultados práticos. Em termos estritamente econômicos não há custos. Trata-se de um investimento no aprimoramento da sociedade; inclusive porque, na outra ponta, o Estado e/ou Município irão deixar de pagar uma pesada fatura médico-hospitalar"19.

Os respectivos trechos exibidos pelo programa, assim como tantos outros já mencionados, evidenciam uma das estratégias da necropolítica - a ocupação colonial ${ }^{26}$. A ação principal se firma na autorização da ação de não deixar pessoas com características específicas não nascerem, do direito de exterminar em um determinado território, em um domínio de território que é legitimado pelo Estado, no qual existem corpos feitos para matar ${ }^{27}$.

Tratamos a ocupação colonial não só a partir dos seus contornos geográficos. A ocupação colonial se expressou, dentro da perspectiva ideológica do PTP, desde o marcar o território soteropolitano como um espaço de escravização de pessoas negras até a afirmativa de que na cidade existiam muitos 'doentes improdutivos', sendo a sua maioria negra e pobre e que, por isso, um projeto que visava a 'uma nova geração de pessoas' a baixo custo, deveria ser implementado.

Deste modo, ressaltamos a pergunta feita por Pessanha, "se a necropolítica se refere ao extermínio de corpos de populações inteiras não seria então esse fenômeno um genocídio?”²7 (p. 39). 


\section{Mobilização das pessoas com doença falciforme para impedir o Programa de Triagem Populacional}

Desde as primeiras aparições do PTP, tal como o documento ‘Triagem Populacional para Identificação de Hemoglobinas Mutantes e Aconselhamento Genético em nosso meio', a Abadfal externou sua preocupação com o discurso emitido, enviando, inclusive, uma Carta ao Comitê de Hemoglobinopatias do Ministério da Saúde e Gerência Sangue Anvisa. A carta denúncia da $\mathrm{Abadfa}^{16}$ afirma que “[...] a premissa da não proliferação dos falcêmicos é enfocada, 'como se estes fossem pessoas que não devessem nascer. É a busca da raça perfeita' [...]. O que virá depois de um programa deste? Que outros portadores de outras doenças passarão a ser vistos como indesejáveis ou incapazes para viver?”(destaque nosso).

Após a veiculação do site do Programa de Triagem Populacional e a denúncia da Abadfal, a Secretaria Municipal da Reparação de Salvador - Semur, no final de 2004, emitiu um ofício ${ }^{28}$ à Clínica que ficaria responsável pela triagem, retirando o apoio ao programa, por acreditar que o conteúdo do programa continha 'alegações de cunho racista e eugenista'. Sublinha ainda que "[...] a sociedade competitiva continua criando situações de exclusão e discriminação social para os portadores de determinada necessidade especial - física ou mental - e pessoas que necessitam de ajuda, ignorando-os ou em iniciativas como a defendida por esta instituição que se configura como defesa pelo gradual extermínio/genocídio de um grupo [...] reiteramos nossa repulsa ao conteúdo do texto e desautorizamos o envolvimento do nome da Secretaria Municipal da Reparação em tais ações e declarações".

Consideramos que a própria ação de denúncia ao programa de triagem populacional feita pela Abadfal contribuiu para o posicionamento da Semur. Além de cumprir um papel de controle social, a associação também exerceu um trabalho educativo, evidenciando o conteúdo do programa e a sua similaridade com políticas racistas e eugênicas.

Entende-se que o Programa de Triagem Populacional não só opera o direito de matar, mas também, especialmente, o exercício de não deixar nascer, e justifica essa ação a partir de uma política concreta de financiamento e gastos na saúde pública, argumento esse que serviu para angariar o apoio da Prefeitura Municipal de Salvador, que visava (e ainda visa) à redução de gastos públicos.

Assim, questionamos qual o custo dessa ação de triagem populacional para além do custo financeiro? Qual o custo de violar diretamente corpos majoritariamente negros e femininos? Pessanha ${ }^{27}$ sublinha que uma sociedade ancorada na necropolítica "[...] custa a vida de milhões de corpos, e, como se já não fosse pouco, custa o conhecimento produzido por esses corpos também. [...] A política da morte avança, e a cada passo ela se torna mais sofisticada. Deixa de se restringir aos perímetros geográficos, como previa o modelo da ocupação colonial tardia,

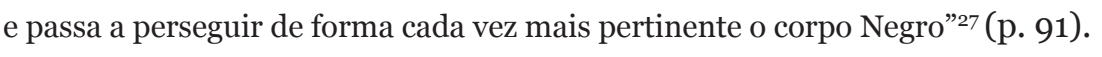

Destarte, os enunciados discursivos do programa vão para além da ideia de que 'doentes' custam caro para o SUS, demonstram um discurso que coloca o corpo das pessoas negras, de baixa renda e com doença falciforme como corpos que representam uma ameaça ao 'aprimoramento da sociedade' e, portanto, são corpos que precisam ser exterminados, para que a sociedade alcance a sua excelência em gerações saudáveis.

A proposta do programa afirmava, ainda, que o seu desenvolvimento iria suprir uma necessidade, trazendo repercussões e efeitos reprodutivos fundamentais para o futuro da sociedade. Numa cidade como Salvador (Bahia), cuja população negra alcança quase $80 \%$ e onde a incidência do traço falciforme é de 1 a cada 17 pessoas, que impactos esse programa representaria?

O PTP é atravessado por diversos elementos - racismo, eugenia, prevenção e enunciados negativos a respeito das pessoas que têm traço e doença falciforme. Tal programa difundiu discursos que previam a redução sistemática de pessoas com doença falciforme com a utilização da informação e comunicação, questão que atinge diretamente a vida das interlocutoras que relataram suas percepções sobre o PTP neste estudo - mulheres negras com DF. 
O Programa de Triagem Populacional exteriorizava uma estratégia de prevenção que tinha a população pobre e uma doença genética prevalente na população negra como bússola, população considerável descartável que não precisaria nem existir.

Nesse sentido, o PTP representa também um caso de racismo institucional. Tal como assinala Silvio Almeida $^{29}$, o racismo institucional não pode ser apreendido apenas a partir das práticas individuais, há uma reprodução social desse sistema. Isto é, "[...] o resultado do funcionamento das instituições, que passam a atuar em dinâmica que confere, ainda que indiretamente, desvantagens e privilégios a partir da raça”"29 (p. 29). Com base nesta perspectiva, é possível dizer que o Programa de Triagem Populacional foi utilizado como um instrumento institucional para impor um interesse político e econômico de prevenir uma população dita 'doente', 'improdutiva', pobre e negra.

\section{Considerações finais}

Buscou-se aqui problematizar a relação entre eugenia e racismo a partir de um programa de triagem populacional. O PTP analisado neste artigo utilizou a informação e a comunicação como ferramentas para concretizar uma política racista e eugenista. Ao integrar em si as teorias eugenistas do século XX vinculadas às questões raciais e reprodutivas, afirma uma nova identidade de propostas de políticas de saúde, nos anos 2000, ancorada na sociedade capitalista-patriarcal-racista. Considerar a doença falciforme como uma 'doença do corpo negro' ou 'doença do sangue ruim' serviu como uma luva para a justificativa de programas propondo redução ou prevenção de pessoas com a doença genética. Ou seja, justificou (e ainda justifica) práticas realizadas, sob os moldes de um discurso eugenista e racista, em determinadas populações.

O racismo não designa apenas o sujeito a ser eliminado, mas também a cor e a classe desse sujeito. O PTP expôs o seu objetivo: evitar a reprodução de pessoas com doença falciforme. Quem são essas pessoas? Qual a raça/etnia delas? Em sua maioria, qual a sua situação econômica? Tais perguntas são compreendidas sob a ótica da necropolítica ${ }^{24}$, que determina o direito de matar e de viver, e para além disso, o direito de não existir.

O PTP colocou prescrições que interfeririam na garantia dos direitos reprodutivos, e sua análise permite acentuar os percalços enfrentados pelas pessoas com doença falciforme, especialmente as mulheres negras. Vale notar, que o programa foi homogeneizante, ao desconsiderar as singularidades das pessoas afetadas pela DF e as multiplicidade de situações e contextos que poderiam envolver a questão reprodutiva, incluindo as possibilidades de cuidados para minimizar as intercorrências.

Questionamos o porquê da emergência desse Programa de Triagem Populacional na cidade de Salvador, no ano de 2004. Compreendemos que, mesmo com as intensas lutas dos movimentos sociais, assim como a contribuição de pesquisadoras(es) e profissionais comprometidas(os) com a qualidade de vida das pessoas com DF, a sociedade brasileira ainda apresenta o racismo como principal instrumento de política de morte, tendo em vista os alarmantes números que denunciam o genocídio da população negra. Assim, a sociedade é favorável à criação de estratégias de prevenção - que remete à eugenia - financiadas pelos governos, o que torna um desafio para a garantia de um cuidado integral isento de discriminações.

Em contraponto ao Programa de Triagem Populacional, foi desenvolvido em 2005 o Programa Municipal de Atenção às Pessoas com Doença Falciforme - PAPDF, que visa à qualidade de vida, à integralidade e, acima de tudo, entende as pessoas com doença falciforme como sujeitos de direitos, e não como um corpo doente a ser prevenido. O PAPDF foi uma conquista das pessoas com doença falciforme e de seus familiares.

A invisibilidade da doença falciforme durante décadas demonstra, além da fragilidade das políticas do Estado e as suas formas de intervenções que se pautam na prevenção da doença por meio da eliminação das pessoas com DF, ser uma política mundial eugenista. 
Há necessidade de destituir práticas institucionais que se forjam sob o crivo do racismo institucional e do sexismo e produzem violências sobre os corpos negros e femininos. Destarte, a luta passa, necessariamente, pela concretização das políticas do Sistema Único de Saúde, combatendo todas as formas de iniquidades sociais, raciais e de gênero.

\section{Referências}

1. Stepan NL. A hora da eugenia: raça, gênero e nação na América Latina. Rio de Janeiro: Editora Fiocruz; 2005.

2. Aguilar Filho S. Educação, autoritarismo e eugenia: exploração do trabalho e violência à infância desamparada no Brasil (1930-1945) [tese]. Campinas: Universidade Estadual de Campinas; 2011.

3. Kern GS. Biopoder e a constituição étnico-racial das populações. Racialismo, eugenia e a gestão biopolítica da mestiçagem no Brasil. Cad IHU Ideias [Internet]. 2015 [acesso em 2020 abr. 09];13(230). Disponível em: https://bit.ly/2wqZx48.

4. Chaturvedi S, DeBaun MR. Evolution of sickle cell disease from a life-threatening disease of children to a chronic disease of adults: the last 40 years. Am J Hematol. 2016. Jan;91(1):5-14.

5. Tapper M. In the blood: sickle cell anemia and the politics of race. Philadelphia: University of Pennsylvania Press; 1999.

6. Cavalcanti JM. Doença, sangue e raça: o caso da anemia falciforme no Brasil, 1933-1949 [dissertação]. Rio de Janeiro: Fundação Oswaldo Cruz; 2007.

7. Cavalcanti JM, Maio MC. Entre negros e miscigenados: a anemia e o traço falciforme no Brasil nas décadas de 1930 e 1940. Hist Ciên Saúde - Manguinhos. 2011 abr.-jun.;18(2):377-406.

8. Creary MS. Biocultural citizenship and embodying exceptionalism: biopolitics for sickle cell disease in Brazil. Soc Sci Med. 2018. Feb;199:123-31.

9. Mota C, Trad LAB, Queiroz MCA, Dias, ALA. Os desafios do cuidado integral à doença falciforme sob diversos olhares: o olhar da gestão, o olhar das famílias e usuários e o olhar do serviço e seus profissionais. In: Castellanos M, Trad LAB, Jorge MSB, Leitão IMTA, organizadores. Cronicidade: experiência de adoecimento e cuidado sob a ótica das ciências sociais [Internet]. Fortaleza: EdUECE; 2015 [acesso em 2020 abr. 09]. p. 392-425. Disponível em: https://bit.ly/34pkvwQ.

10. Berghs M, Dyson SM, Atkin K. Resignifying the sickle cell gene: narratives of genetic risk, impairment and repair. Health (London). 2017 Mar;21(2):171-18

11. Cançado RD, Jesus JAA. A doença falciforme no Brasil. Rev Bras Hematol Hemoter. 2007;29(3):203-6.

12. Lira AS. Análise da assistência ofertada às gestantes com doença falciforme, em Salvador - BA: o racismo nas tramas e enredos das redes do SUS [dissertação]. Salvador: Universidade Federal da Bahia; 2015.

13. Oliveira F. Feminismo, raça/etnia, pobreza e bioética: a busca da justiça de gênero, antirracista e de classe. In: Garrafa V, Pessini L. Bioética: poder e injustiça. Brasília: Loyola; 2003.

14. Diário Oficial do Município. Salvador, BA. Prefeitura Municipal de Salvador. Ano XVII. Número 3.611. p. 1-22. 8. jan. 2004.

15. Diário Oficial do Município. Salvador, BA. Prefeitura Municipal de Salvador. 12 de janeiro de 2004.

16. Abadfal. Carta aberta à população: convênio Cephar. Secretaria Municipal de Saúde, Salvador/BA. Salvador: Abadfal; 2004.

17. Ávila MB. Feminismo e sujeito político. Rev Proposta. 2000;29(84-85):6-11.

18. Foucault M. A arqueologia do saber. Rio de Janeiro: Forense Universitária; 2012.

19. Triagem e informação genética em idade reprodutiva [Internet]. 2004. Disponível em: www.falcemia. med.br/presente.html. Página desativada em 2004.

20. Oliveira F. Feminismo, luta antirracista e bioética. Cad Pagu. 1995;(5):73-107. 
21. Silva EG, Fonseca $A B C$. A construção da raça nacional: estratégicas eugênicas em torno do corpo da mulher. In: Batista LE, Werneck J, Lopes F, organizadores. Saúde da população. 2 ed. Brasília: ABPN; 2012. p. 240-261. (Coleção Negras e Negros: Pesquisas e Debates).

22. Dias ALA. A (re)construção do caminhar: itinerário terapêutico de pessoas com doença falciforme com histórico de úlcera de perna [dissertação]. Salvador: Universidade Federal da Bahia; 2013.

23. Souza CG. O campo da anemia falciforme e a informação genética: um estudo sobre o aconselhamento genético [dissertação]. Brasília: Universidade de Brasília; 2006.

24. Diniz $D$, Guedes $C$. Informação genética na mídia impressa: a anemia falciforme em questão. Ciênc Saúde Coletiva. 2006;11(4):1055-62.

25. Caponi S. Loucos e degenerados: uma genealogia da psiquiatria ampliada. Rio de Janeiro: Editora Fiocruz; 2012. Introdução; p. 19-29.

26. Mbembe A. Necropolítica. Arte Ensaios 2016 dez.;32:123-51.

27. Pessanha EAM. Necropolítica e epistemicídio: as faces ontológicas da morte no contexto do racismo [dissertação]. Brasília: Universidade de Brasília; 2018.

28. Ofício no 341, Secretaria Municipal da Reparação. Salvador, 30 de novembro de 2004.

29. Almeida SL. O que é racismo estrutural?. Belo Horizonte: Letramento; 2018. 